Article

\title{
Environmental Performance through Environmental Resources Conservation Efforts: Does Corporate Social Responsibility Authenticity Act as Mediator?
}

\author{
Abdelmohsen A. Nassani ${ }^{1}$ (D), Zahid Yousaf ${ }^{2, *(D)}$, Magdalena Radulescu ${ }^{3,4}$ and Mohamed Haffar $^{5}$ (D) \\ 1 Department of Management, College of Business Administration, King Saud University, P.O. Box 71115, \\ Riyadh 11587, Saudi Arabia; Nassani@ksu.edu.sa \\ 2 Higher Education Department, Government College of Management Sciences, Mansehra 23100, Pakistan \\ 3 Department of Finance, Accounting and Economics, University of Pitesti, Str. Targu din Vale, no.1, \\ 110040 Pitesti, Romania; magdalena.radulescu@upit.ro \\ 4 Institute of Doctoral and Post-Doctoral Studies, University Lucian Blaga of Sibiu, Bd, Victoriei, no. 10, \\ 550024 Sibiu, Romania \\ 5 Department of Management, Birmingham Business School, University of Birmingham, \\ Birmingham B15 2TT, UK; m.haffar@bham.ac.uk \\ * Correspondence: muhammadzahid.yusuf@gmail.com
}

check for

updates

Citation: Nassani, A.A.; Yousaf, Z.;

Radulescu, M.; Haffar, M.

Environmental Performance through

Environmental Resources

Conservation Efforts: Does Corporate

Social Responsibility Authenticity

Act as Mediator? Sustainability 2022,

14, 2330. https://doi.org/10.3390/

su14042330

Academic Editor: Anna Mazzi

Received: 25 January 2022

Accepted: 15 February 2022

Published: 18 February 2022

Publisher's Note: MDPI stays neutral with regard to jurisdictional claims in published maps and institutional affiliations.

Copyright: (c) 2022 by the authors Licensee MDPI, Basel, Switzerland. This article is an open access article distributed under the terms and conditions of the Creative Commons Attribution (CC BY) license (https:// creativecommons.org/licenses/by/ $4.0 /)$.

\begin{abstract}
This study shows the impact of environmental resources conservation efforts (ERCE) and corporate social responsibility (CSR) authenticity on environmental performance (EP) in the hospitality and tourism industry. A mediating role of CSR authenticity between the ERCE and environmental performance link is also checked. A quantitative research design has been employed, and data were collected through a questionnaire. Results show that both ERCE and CSR authenticity positively influence environmental performance. Results also show that CSR authenticity act as a mediator, which enhances the positive impact of ERCE on environmental performance. Environmental performance is a broader concept, and its achievement is majorly dependent on the attraction of stakeholders. This study points out that stakeholders should be more concerned with environmental management's initiatives in terms of resource conservation efforts and organization involvement in CSR activities for achieving the environmental performance goal. ERCE is a pre-condition for an efficient involvement in CSR-related activities to achieve environmental performance.
\end{abstract}

Keywords: environmental resources conservation efforts; CSR authenticity; environmental performance; hotel and tourism industry; environmental management system

\section{Introduction \\ 1.1. Background}

Environmental threats such as air pollution, warming, increased use and waste of natural resources, and CO2 emission emerged in the world economy during the 1990s [1]. The interplay between environmental policies and eco-economic performance at both microeconomic and macroeconomic levels has gained importance for all types of organizations [2,3]. Organizations have faced an increasing social demand for reducing the adverse effect of environmental impact [4].

The tourism sector is pertinent for the economic growth and the economic development of the worldwide countries, but also considering the impact of this growing sector on the waste of natural resources or on the environment, the concept of sustainable tourism emerged as the best way to deal with negative effects of the tourism-led developments [5,6]. For developing countries that lack substantial domestic financial resources, analyzing the relation between tourism growth and its impact on the environment is even more interesting and important. 
The CSR importance for the tourism and hospitality sector has been very debated in the latest research due to its increasing contribution in supporting sustainable development [7]. Some studies demonstrated that environmental-friendly practices were mainly adopted by world-chain affiliated hotels and less by the local non-affiliated ones [8]. Companies that are aware of their impact on wasting natural resources tend to adopt more voluntary environmental managerial initiatives according to ISO14001, and that leads to the improvements of their environmental performance [9]. Still, the results are mixed and not very conclusive in the empirical research.

\subsection{Research Gap}

Managing environmental performance is an important task for organizations, and this shift of focus is more profound in the hospitality and tourism industry [10]. The hospitality and tourism industryis paying more attention to environmental concerns due to stakeholder pressure [11]. The authors [12] found that the attitude and the pressures of the stakeholders towards adopting environmental measures in the companies are pertinent indicators that increase the environmental performance of the companies. Poor environmental behavior may determine a real adverse impact on firms and on the firms' economic performance (negatively affecting brand values, generating financial losses, loss of insurance cover, and damaging the market image of the firms) [13]. Hence, a deeper understanding is required to properly utilize environmental resources and authentic corporate social responsibility (CSR authenticity) initiatives for achieving the overall environmental performance of the hospitality and tourism industry. However, existing studies lack providing any evidence about the nexus of environmental resource conservation efforts and CSR authenticity towards the environmental performance of the hospitality and tourism industry in developing nations so far. The current research fills this research gap through offering and identifying that environmental management system (EMS), in terms of environmental resource conservation efforts (ERCE) and CSR authenticity, can lead to increased environmental performance (EP).

\subsection{Need of Environmental Performance in Organizational Context}

After the introduction of ISO 14001, the ERCE gained importance as it implies that this system is necessary in order to reduce waste and pollution and improve environmental performance [14]. Previous studies have demonstrated that firms that have implemented EMS display a large impact on their environmental performance and on the selection and use of environmental resources [15]. However, improving organizational environmental performance is not usually the main reason for adopting an EMS [11,16]. Moreover, small firms usually adopt EMS to comply with the environmental regulations, while large firms that adopt EMS are more interested in improving their market image [11]. There are many factors impacting EMS adoption: some of them are environmental policies-related, and others are represented by the market or firms' features and aims or by the financial constraints of the firms [17]. That is why well-designed public policies, technical assistance, and employees' training programs can support the implementation of EMS, especially for small firms [18]. The current study shows how the hospitality and tourism industry of developing nations can attain environmental performance through ERCE.

Additionally, due to very little attention paid to the ERCE and environmental performance link, the stance of this research is meager at best for the underlying link of ERCE and environmental performance. The recent study conducted by [1] accentuates that CSR-related factors can also determine environmental performance, and EMS alone is insufficient to determine environmental performance. The work of previous and existing researchers had glossed over the inter-relations between ERCE, CSR authenticity, and environmental performance. To overcome this research gap, this study proposes that CSR authenticity, i.e., being an important outcome of EMS, should mediate the ERCE and environmental performance link. Similarly, the available stream of literature regarding environmental performance pertaining to the hotel and tourism industry remained unsuc- 
cessful in drawing attention to any link between ERCE and environmental performance through CSR authenticity.

CSR authenticity initiated through ERCE improves organizational trustworthiness, honesty, and realness of the organization's CSR actions, hence fulfilling its stakeholders' perceptions, whether or not organizations are truly responsible for social demands and are engaged in real CSR actions [19]. Although there are many studies on this topic, the findings of the empirical analyses are not very conclusive because previous research has focused mainly on the direct benefits of environmental policies. This doesnot necessarily support the environmental performance of the companies and does not reduce pollution. This study shows that CSR authenticity is a major outcome of ERCE and helps to improve environmental performance, and the role of ERCE is an integral part of rethinking this mechanism.

In the last years, CSR actions were successfully integrated into the overall management of the companies [20]. CSR activities are considered strategic tools for improving a company's sustainable growth and essential for corporate management activities [21]. Environmental-related requests from the suppliers, investors, consumers, and government determine the companies to participate in CSR-related activities in order to increase their environmental performance [2]. ERCE helps to develop environmental policies and develop a platform to erect CSR authenticity.

Environmental management system promotes green hotels [14]. Environmental policies are more concerned with society and betterment infrastructure [14,22]. The high-ranked hotels are used by international visitors, i.e., celebrities, government delegations, tourists, etc., and they have to follow the international policies regarding environmental concerns. The environmental management initiatives in terms of resources conservation efforts greatly influence the involvement of CSR authenticity in adopting an environmental and eco-friendly behavior [23-25]. Such CSR authenticity can determine the achievement of environmental sustainability and performance [26]. CSR authenticity developed through ERCE confirms environmental protection, and these two factors can be considered as major antecedents of environmental performance [27].

\subsection{Tourism and Hospitality}

The tourism and hospitality sectors have to deal with the same issues as all the economic sectors if we consider the waste of resources such as water or energy [28,29]. Some recent studies have proven a bi-directional causality between the tourism arrivals and $\mathrm{CO} 2$ emissions, meaning that tourism negatively impacts environmental pollution and the pollution also causes the decrease in the number of tourists [30]. Thus, the environmental issues should be prioritized, and implementing the environmental management initiatives for conserving the natural resources should become a major priority for the hotel and hospitality actors, especially in developing economies that lack strict environmental regulations and face increasing pollution. The managers have the task to support and ensure the environmental performance in those industries [31]. Hospitality and hotel sectors need to involve in CSR-related activities to achieve their environmental targets and to gain competitive advantages $[14,24]$. The existing research has emphasized that fulfilling the CSR duties in the hotel and hospitality sectors is very important [32] because tourists and all other stakeholders are interested in the authenticity of CSR environmental-related activities and the environmental performance of the hotels and hospitality sector. This is why we consider it is important to analyze this specific industry. The tourism sector is growing in this country, and its role in economic growth and development is undeniable.

The tourism sector faces numerous environmental issues, which include water pollution, air pollution, noise pollution, pesticide misuse, climate change, soil erosion, desertification, natural disasters, flooding, etc. [1]. Unfortunately, tourism activities are facing tremendous ups and down every year.The main factors that are negatively affecting Pakistan's tourism industry are under development, marginality, fragility, and continuous political and social instability. Apart from this, different governments have made policies 
to develop and grow the tourism industry of the country; however, most of them did not implement this due to one reason or another [33]. To ensure improvement in the tourism industry, the government and its functionary bodies are required to show seriousness and take necessary actions such as up-gradation of tourism infrastructure, controlling the insurgency at the earliest, strengthening its foreign relations.

A deeper analysis of the developing countries related to their tourism sector, its environmental performance, CSR, and environmental management initiatives for conserving the natural resources is very necessary in order to design an appropriate model of sustainable development for this sector and for the companies activating in the hotel and hospitality area.

\subsection{Structure of Paper}

This study aims to develop an environmental performance model for the hospitality and tourism industry. For the development of the research model, this study identifies that ERCE and CSR authenticity predicts environmental performance. This study also investigated the mediating role of CSR authenticity between ERCE and environmental performance links. To complete the research study, the remained sections are arranged systematically. The next section shows a literature review. Then, the methodology is presented. Next, analysis is presented, and finally, the discussion and research implications are discussed. The theoretical framework of this research is presented in Figure 1.
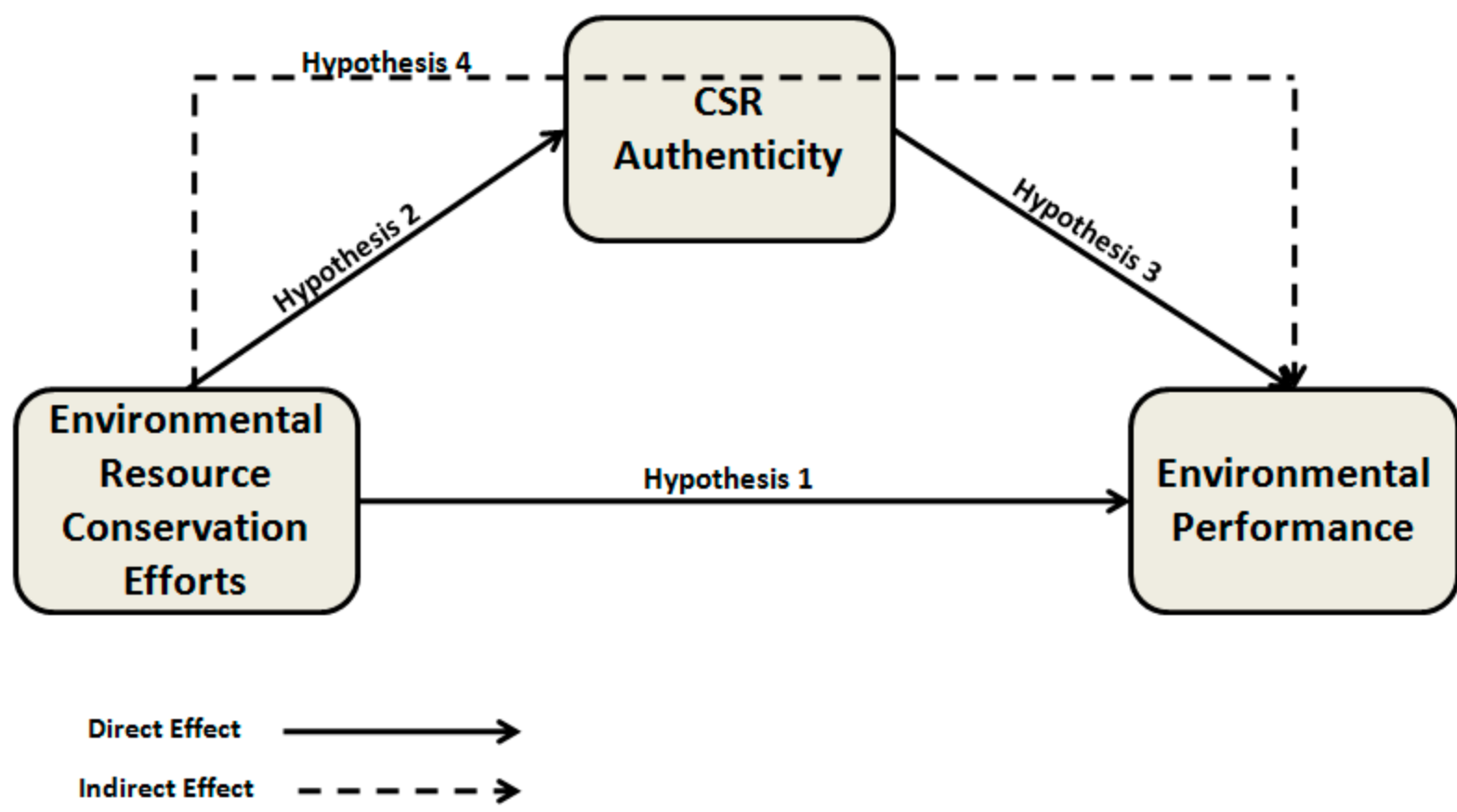

Figure 1. Theoretical Framework.

\section{Development of the Research Model}

\subsection{Environmental Resource Conservation Efforts and Environmental Performance}

Environmental Performance (EP) refers to all those activities that are initiated to clean the environment from all aspects. EP enables firms to utilize resources, save energy and water capability, minimize pollution through extended reuse and reusing, and the abatement of dangerous waste and unsafe defilements [34,35]. Environmental-resource conservation efforts are the practice of the skillful and rational management and use and protection of natural resources of the environment. It helps to boost and improve environmental performance through natural environmental resources for the advantage of mankind. Environmental performance is linked to those activities that help to clean all aspects of the environment. It facilitates firms to save water and energy capability, 
utilize the resources and reduce pollution from expanded reusing and ending of unsafe and dangerous defilements and waste. Previous research highlighted that environmental performance begins through diverse factors, such as green environment management, feminine leadership, financial resources, etc. Though, the critical factor in achieving better environmental performance was policies concerned with environmental-resource conservation efforts. Prior researchers have found a variety of determinants that are linked with environmental performance except for initiatives of environmental management that are likely to be related to the objectives of the company.

Recent researchers have highlighted that environmental performance is initiated through different factors, for example, financial availability [10,35], green HRM, feminine leadership [36], etc. However, the most important factors to improve environmental performance are environmental policies regarding resources conservation efforts, and this link has been skipped. Researchers have mentioned various determinants of environmental performance other than environmental management initiatives, and these are seldom disclosed explicitly in the literature and are more likely to be specifically orientated towards the company's objectives $[10,25]$. This study proposed that ERCE has the significant control to shape overall environmental performance through protecting the environment and properly utilizing resources.

Environmental resources conservation is a process of rational use and proficient management and conservancy of the natural environment with all its resources [37]. Environmental resource conservation efforts identify factors affected by conflicts that arise between fulfilling needs and securing resources. It is consequently linked to the environment, sustainability, integrated landscape, natural resource, fisheries, forest, wildlife, and others [38]. Hence, ERCE is a competing force to encourage the mechanism of improving environmental performance. The organization's ERCE is a major contributor to the improvement and development of environmental performance [10]. An organization's inclination towards conservation of resources can protect the natural environment and utilize resources that are necessary to attain environmental performance. Hence, organizations having sound environmental policies regarding ERCE can achieve the goals of environmental performance. Environmental-resource conservation-effort mainly helps to control whole environmental performance by properly protecting and utilizing natural resources. Environmental-resource conservation efforts recognize various factors that influence conflicts that augment between the fulfillment of needs and the protection of resources. Environmental performance is associated with integrated landscape, sustainability of the environment, fisheries, forests, and natural resources. Therefore, environmental resource-conservation efforts encourage and improve mechanisms of environmental performance. A firm's environmental resource-conservation efforts are the most important contributor to the development and improvement of environmental performance. Their leaning towards resource conservation facilitates society to carefully utilize and protect resources of the natural environment, which is important to achieve improved environmental performance. So, firms with sound policies about environmental resource-conservation efforts can acquire goals of the environmental performance. All discussion shows that ERCE supports the organizations to improve environmental performance, so we develop the following hypothesis:

Hypothesis 1 (H1). Environmental Resource conservation efforts predict environmental performance.

\subsection{Environmental Resource Conservation Efforts and CSR Authenticity}

CSR authenticity refers to the responsibility, honesty, and realness of an organization's CSR actions according to the perceptions of its stakeholders, i.e., how an organization is truly involved in socially responsible practices [19]. CSR authenticity refers to the responsibility, trustworthiness, realness, honesty, and genuineness of a firm's participation in the CSR actions perceived by its stakeholders, such as how a firm is involved in socially responsible activities truly. CSR authenticity proves that firms are responsible for the social 
environment and engagement in CSR actions. The involvement degree of the environmental resource-conservation efforts affects means that stakeholders used to evaluate the firm's participation in the CSR related practices in their operations. The problems of the environment influenced organizations to implement environmental resource-conservation efforts to boost the number and quality of CSR-related practices. Environmental resourceconservation efforts positively affect the involvement of the firms in the CSR authenticity and help in the adoption of eco-friendly behavior. A lower level of environmental resource-conservation efforts encourages unfavorable opposing perceptions and views of the stakeholders about CSR authenticity practices of the firm. Most stakeholders choose those firms that are linked with green environmental activities and use natural resources that certify CSR authenticity in its practices. Furthermore, organizations that are not or less equipped with environmental resource-conservation efforts face negative reactions and hurdles from the stakeholders.

Environmental problems determine organizations to adopt environmental management actions to increase the number and the quality of CSR-related activities [22]. The environmental management initiatives in terms of conservation efforts of the environmental resources positively influence the involvement of organizations in CSR-related activities and in adopting an environmental and eco-friendly behavior [23].Stakeholders prefer those organizations which are involved in green environmental actions and utilize natural resources to authenticate CSR actions in their operational activities. Moreover, those organizations which are not equipped with environmental policies face difficulties and negative reactions from stakeholders $[39,40]$. Hence, this study argues that it is necessary to build a strong environmental management system in terms of ERCE for improving CSR authenticity [23]. One explanation for that can be represented by the fact that organizations adopting CSR-related measures in the environment protection area consider that as being the main concern of all their interested parts [27]. One of the pertinent areas of being socially responsible and CSR authenticity is mainly dependent on organizations' interest in environmental resources conservations [19]. The organizations with high environmental resource-conservation efforts obtain attention from the stakeholders and the society for the improvement and enhancement of the CSR authenticity. So, this research proposed that environmental resource-conservation efforts are essential for improving and increasing CSR authenticity in firms. If a firm adopts environmental resource-conservation efforts to increase CSR authenticity for the protection of the environment and utilization of the natural resources, then a sense of higher CSR authenticity is generated through ERCE.

\section{Hypothesis 2 (H2). Environmental Resource Conservation Efforts predicts CSR authenticity.}

\subsection{CSR Authenticity and Environmental Performance}

CSR authenticity refers to the perception of the society and the stakeholders that are linked with firms that perform CSR activities for improvement and protection of the environmental performance. CSR authenticity contains practices concerned with CSR actions related to the protection of environmental performance, which is disturbed through business activities [19]. It is observed that firms are concerned about issues that they are accountable for, such as environmental, social, and economic concerns. These issues influence and force organizations to participate in CSR authenticity practices for the improvement of environmental performance. CSR authenticity forecast environmental performance because it aids to improve and protect natural resources and the environment. A firm's engagement in CSR activities improves society's beliefs and well-being that plays a critical role in the improvement of environmental performance. CSR authenticity is the sincerity, honesty, genuineness, and trustworthiness of the firm's involvement and participation in activities that enhance environmental performance. Higher CSR authenticity levels of the firm, related to CSR actions improve the environmental performance. CSR authenticity can predict environmental performance as it helps to protect the natural environment $[10,14]$. The argument that CSR authenticity is a major antecedent of environmental performance 
is recognized as the organization's participation in environment-related actions beyond their routine work boost up its environmental efficiency [25,34]. Since CSR authenticity consists of stakeholders' positive perception regarding CSR activities, it is logical to argue that stakeholders' perception positively affects environmental performance [10].

Existing research for the developing countries demonstrated how initiatives of CSR solved in time many problems in the labor market area or some unemployment and environmental issues [10,41].Although the environmental issues represent a part of CSR, CSR does not exclusively target the environmental objective and the environmental performance of the organizations [42].When a company adopts the decision to integrate CSR into its strategy, the organization should be authentic and transparent with the CSR approach, which positively influences environmental performance [10]. CSR authenticity is the important ancestor of environmental performance as organizations participate in the green environment actions away from routine work to increase their environmental efficiency. However, CSR authenticity is the positive perception of the stakeholders related to CSR activities/practices which positively enhance environmental performance. Previous researchers demonstrated how CSR practices solved many issues in the labor market and some environment-related issues even though issues of environment are part of the CSR, as CSR doesnot entirely target the objectives of environmental performance. An organization, when adopting decisions to incorporate CSR into the strategy, should be transparent with the CSR approach, which affects environmental performance positively. It can be hypothesized that.

Hypothesis 3 (H3). CSR authenticity predicts environmental performance.

\subsection{CSR Authenticity as Mediator}

This research suggests that CSR authenticity act as a mediator between the environmental resource-conservation efforts and the environmental performance link. Firms' initiatives related to CSR practices are important for the improved environmental performance of the organization. However, it does not mean that environmental resource-conservation efforts are enough for the improvement and benefit of society and the environment. CSR authenticity is critically needed to consider for organizations as a mediating construct between the environmental resource-conservation efforts and the environmental performance. It is evident that CSR authenticity is the sincerity, honesty, genuineness, and trustworthiness of the firm that enhance environmental performance. Previous research in literature mainly focuses on the relation between CSR authenticity initiatives and customer loyalty and employee commitment in developing countries.

Many existing studies in the literature focused mainly on analyzing the relation between the CSR initiatives, the CSR authenticity, and building the customers' loyalty or employees' commitment, especially in the developing countries. Some studies have proved that CSR authenticity displays a mediating role for the consumers' loyalty and that it is not enough just to involve in CSR-related activities. It is important that consumers think about the CSR initiatives as being authentic [19].Other studies have demonstrated that the internal CSR legitimacy (not the external one) increased the employees' perception of CSR authenticity. The authors [39] have demonstrated that CSR authenticity is an important mediator between what employees think about CSR legitimacy and their commitment to work in the organization frame. Few recent studies started to analyze the relation between CSR-related activities and the environmental performance of the companies in different sectors. The authors [43] have studied the relation between environmental performance and CSR-related activities for the food industry in China and found a positive and significant relationship. On the contrary, [44] found in their study that CSR is not significantly associated with the environmental sustainability of Indian firms. The authors of [1] analyzed the impact of the CSR commitment on the social and environmental performance of the companies in the hotel and tourism sector and found a positive and significant relation mediated by the CSR participation of the firms. 
The relative lack of empirical studies and their mixed results, especially for the developing countries, can be explained by the difficulty to measure all the dimensions of CSR-related activities and to measure the ratios expressing the environmental performance of the companies [10].This study fills that gap and extends the existing research on this topic by analyzing the relation between the efforts to conserve the environmental resources (as part of the environmental management initiatives) and the environmental performance of the organizations mediated by the CSR authenticity. This study has disclosed that CSR authenticity is the vital mediator between the environmental resource-conservation efforts and the environmental performance in various sectors. CSR authenticity act as the base for an organization's environmental resource-conservation efforts, which promotes a positive perception of stakeholders about the organization related to trustworthiness and the sincerity in the CSR actions, which eventually enhances the environmental performance of the firm. CSR authenticity acts as the bridge between the environmental resource-conservation efforts and the environmental performance because environmental resource-conservation efforts force organizations to participate in CSR-related actions and activities, which facilitates firms to promote environmental performance. Thus, we focused on environmental resource-conservation efforts' effects to save natural resources of the environment and also CSR authenticity impact on environmental resource-conservation efforts of the company, which in turn improve environmental performance.

Hypothesis 4 (H4). CSR authenticity mediates the relationship between ERCE and EP.

\section{Methodology}

Current study is based on cross-sectional research design, and hotel businesses are considered as unit of analysis.

\subsection{Sampling}

The owners or managers of these hotels were contacted by telephonic conversation to explanation for the aim of research and to offer them to participate in the study. These respondents include managers QEC (Quality Enhancement Cell; Product); Operational Managers, Manager Public Dealing product), operational managers, manager public dealing, etc. Questionnaires were sent by email. Complete feedback of questionnaires as incentive for participation. The design of questionnaire was developed on the Google Docs platform and covered all data from being omitted. Out of the 600 questionnaires, we received 319 valid responses. The details of respondents are shown in Table 1.

Data for the study was gathered in two stages to enhance responses [45,46]. Before collecting the full datasets, we conducted a pilot test on 35 managerial officials from the said hotels [47].

\subsection{Scale Measurement}

\subsubsection{Environmental Resource Conservation Efforts}

Environmental resource conservation efforts were measured with a 14-items scale developed by Lin et al., [25] and adapted for our survey. This construct was based on questions about the management efforts towards saving resources for the betterment of environment. Respondents were asked to report how hotel equipment and electronics are energy efficient. How wastes are properly disposed of and water management system of hotel properly installed to save resources.

\subsubsection{CSR Authenticity}

CSR authenticity was measured with 8-item scale adapted from Alhout et al. [19].This issue is asked from the respondents, such as what are the actual CSR efforts and how these are projected before stakeholders. Authentic CSR efforts are the main concern for hotel management, and a clear and true picture is presented among employees and general public. 
Table 1. Hotel and Respondent Details.

\begin{tabular}{|c|c|c|}
\hline SR & Demo & Qty \\
\hline & Business-Age (In-Years) & \\
\hline 1 & 15 to 20 Years & 173 \\
\hline 2 & 21 to 30 Years & 117 \\
\hline \multirow[t]{3}{*}{3} & 31 and Above & 29 \\
\hline & Total & 319 \\
\hline & Business Size (No.of Employees) & \\
\hline 1 & Lower 210 employees & 185 \\
\hline 2 & Lower 350 employees & 97 \\
\hline \multirow[t]{3}{*}{3} & Above 400 employees & 37 \\
\hline & Total & 319 \\
\hline & Respondents-Experience & \\
\hline 1 & Lower than 15 years & 187 \\
\hline 2 & Lower than 25 years & 99 \\
\hline 3 & Lower than 35 years & 27 \\
\hline \multirow[t]{3}{*}{4} & Above 40 years & 6 \\
\hline & Total & 319 \\
\hline & Respondent Education & \\
\hline 1 & 10 Years Diploma & 9 \\
\hline 2 & 12 Years Diploma & 11 \\
\hline 3 & Bachelors & 90 \\
\hline 4 & Masters & 187 \\
\hline \multirow[t]{2}{*}{5} & Doctorate & 22 \\
\hline & Total & 319 \\
\hline
\end{tabular}

\subsubsection{Environmental Performance}

Construct of EP was used as a dependent variable and was operationalized by using 15 items formulated by Henri and Journeault [10]. This is a pertinent objective of this study, and it was comprised of all major environmental concerns. Questions include how hotel managementiseager to achieve EP through reducing costs of material, production, effective operations to improve EP. Respondents were also asked to report about innovative ideas to promote EP. Environmental improvements and hotel efforts in connection to; stakeholders, societal groups, and environmental groups related questions were also asked.

\section{Analysis}

This study analysis was conducted using SEM, 'Process' developed by Preacher and Hayes (2008) and Fornell and Lacker (1981) and OLS regression. Bootstrap and indirect effects were conducted to test the mediating analysis.

\subsection{Confirmatory Factor Analysis}

CFA 3-factor model shows model fitness (See Table 2) and proves that data is accurate.

Table 2. CFA Results.

\begin{tabular}{lcccccc}
\hline Model & $\chi^{\mathbf{2}}$ & Df & $\chi^{\mathbf{2} / \mathbf{d f}}$ & RMESA & GFI & CFI \\
\hline Hypothesized 3-factor-model & 912.26 & 380 & 2.401 & 0.044 & 0.96 & 0.95 \\
2-factor-model & 1086.56 & 310 & 3.505 & 0.014 & 0.86 & 0.85 \\
1-factor-model & 1170.87 & 360 & 3.252 & 0.230 & 0.76 & 0.75 \\
\hline
\end{tabular}




\subsection{Validity Test}

Table 3 ensures that convergent and discriminant validity are correct.

Table 3. Results testing F.L, alpha, CR, AVE.

\begin{tabular}{|c|c|c|c|c|}
\hline Constructs & FL & AVE & C.R & Alpha \\
\hline Environmental Resource conservation Efforts & & 0.74 & 0.93 & 0.82 \\
\hline ERCE 1 & 0.81 & & & \\
\hline ERCE 2 & 0.82 & & & \\
\hline ERCE 3 & 0.79 & & & \\
\hline ERCE 4 & 0.83 & & & \\
\hline ERCE 5 & 0.84 & & & \\
\hline ERCE 6 & 0.85 & & & \\
\hline ERCE 7 & 0.86 & & & \\
\hline ERCE 8 & 0.81 & & & \\
\hline ERCE 9 & 0.82 & & & \\
\hline ERCE 10 & 0.84 & & & \\
\hline ERCE 11 & 0.87 & & & \\
\hline ERCE 12 & 0.88 & & & \\
\hline ERCE 13 & 0.89 & & & \\
\hline ERCE 14 & 0.78 & & & \\
\hline ERCE 15 & 0.77 & & & \\
\hline ERCE 16 & 0.82 & & & \\
\hline CSR Authenticity & & 0.76 & 0.95 & 0.85 \\
\hline CSR Au 1 & 0.82 & & & \\
\hline CSR Au 2 & 0.83 & & & \\
\hline CSR Au 3 & 0.85 & & & \\
\hline CSR Au 4 & 0.87 & & & \\
\hline CSR Au 5 & 0.88 & & & \\
\hline CSR Au 6 & 0.86 & & & \\
\hline CSR Au 7 & 0.87 & & & \\
\hline CSR Au 8 & 0.84 & & & \\
\hline Environmental Performance & & 0.75 & 0.96 & 0.86 \\
\hline EP 1 & 0.82 & & & \\
\hline EP 2 & 0.81 & & & \\
\hline EP 3 & 0.84 & & & \\
\hline EP 4 & 0.85 & & & \\
\hline EP 5 & 0.86 & & & \\
\hline EP 6 & 0.82 & & & \\
\hline EP 7 & 0.87 & & & \\
\hline$E P 8$ & 0.89 & & & \\
\hline EP 9 & 0.79 & & & \\
\hline EP 10 & 0.87 & & & \\
\hline EP 11 & 0.88 & & & \\
\hline EP 12 & 0.83 & & & \\
\hline EP 13 & 0.81 & & & \\
\hline EP 14 & 0.78 & & & \\
\hline EP 15 & 0.86 & & & \\
\hline
\end{tabular}

\subsection{Descriptive Analysis}

Table 4 shows that environmental resource conservation efforts are positively correlated with environmental performance $(\mathrm{r}=0.38)$. CSR authenticity is positively associated with CSR authenticity $(r=0.38)$. ERCE is also positively associated with EP $(r=20)$. CSR authenticity is also positively correlated with environmental performance $(r=0.38)$. 
Table 4. Results of Correlations.

\begin{tabular}{|c|c|c|c|c|c|c|c|c|c|c|}
\hline Variable & & Mean & SD & 1 & 2 & 3 & 4 & 5 & 6 & 7 \\
\hline 1 & Business age & 1.21 & 0.44 & 1.00 & & & & & & \\
\hline 2 & Business size & 1.43 & 0.56 & $0.135^{* *}$ & 1.00 & & & & & \\
\hline 3 & Respondent Experience & 3.78 & 0.58 & -0.02 & 0.02 & 1.00 & & & & \\
\hline 4 & Respondent Education & 1.44 & 0.51 & 0.630 & 0.04 & -0.18 & 1.00 & & & \\
\hline 5 & $\begin{array}{l}\text { Environmental Resource } \\
\text { Conservation Efforts }\end{array}$ & 1.77 & 0.62 & 0.680 & -0.029 & -0.01 & -0.02 & 1.00 & & \\
\hline 6 & CSR Authenticity & 1.56 & 0.67 & -0.07 & 0.07 & $0.81 *$ & -0.02 & $0.386^{* *}$ & 1.00 & \\
\hline 7 & $\begin{array}{l}\text { Environmental } \\
\text { Performance }\end{array}$ & 3.45 & 0.63 & -0.02 & -0.02 & -0.07 & -0.05 & $0.201^{* *}$ & $0.381^{* *}$ & 1.00 \\
\hline
\end{tabular}

Note: ${ }^{*}=<0.005,{ }^{* *}=<0.001$.

\subsection{Hypothesis Testing}

Table 5 shows the proposed hypothesis testing. ERCE directly affects the environmental performance $\left(\beta=0.20^{* *}, p=0.000\right.$ sign). On the basis of this result, H1 is supported. ERCE is positively predicted with CSR authenticity $\left(\beta=0.39^{* *}, p=0.000\right.$ sign), hence $\mathrm{H} 2$ is proved. CSR authenticity is positively linked with environment performance $\left(\beta=0.38^{* *}\right.$, $p=0.000$ sign). Results show that H3 is proved and accepted.

Table 5. Results of hypothesis of $\mathrm{H} 1, \mathrm{H} 2$ and $\mathrm{H} 3$.

\begin{tabular}{clccccc}
\hline Model & Details & Beta & T & F & Sig & Remarks \\
\hline 1 & ERCE $\rightarrow$ EP & 0.20 & 11.82 & 34.88 & 0.000 & H1-Supported \\
2 & ERCE $\rightarrow$ CSR Authenticity & 0.39 & 12.21 & 149.26 & 0.000 & H2-Supported \\
3 & CSR Authenticity $\rightarrow$ EP & 0.38 & 16.54 & 140.64 & 0.000 & H3-Supported \\
\hline
\end{tabular}

Table 6 shows the indirect effect of CSR authenticity as a mediator between environmental resource conservation efforts and environmental performance. The mediating test was conducted with the help of indirect effect following the guidelines of Preacher and Hayes $(2004,2008)$. Results show the mediating role of CSR authenticity has positive effects with ERCE with EP. Data $=0.2153$, lower $=0.1569$, Upper $=0.2837$. Table 7 also shows the results of OLS regressions.

Table 6. Indirect effect with Bootstrap Path ab (CSR Authenticity as mediator).

\begin{tabular}{lccccc}
\hline Model Detail & Data & Bias & SE & Lower & Upper \\
\hline $\begin{array}{l}\text { ERCE } \rightarrow \text { CSR Authenticity } \rightarrow \text { EP } \\
\text { Soble Test Z Score }=7.8626\end{array}$ & 0.2153 & -0.001 & 0.033 & 0.1569 & 0.2837 \\
\hline
\end{tabular}

Table 7. OLS regression test (Mediation by CSR Authenticity).

\begin{tabular}{|c|c|c|c|c|c|}
\hline \multirow{2}{*}{ Variables Details } & \multicolumn{3}{|c|}{ DV: CSR Authenticity } & \multicolumn{2}{|c|}{ DV: Environmental Performance } \\
\hline & Model1 & Model2 & Model3 & Model4 & Model5 \\
\hline \multicolumn{6}{|l|}{ Controls } \\
\hline Age & $0.044(0.046)$ & $0.014(0.034)$ & $0.012(0.34)$ & $0.002(0.052)$ & $0.051(0.049)$ \\
\hline Experience & $0.067(0.112)$ & $0.054(0.086)$ & $0.005(0.054)$ & $0.015(0.087)$ & $0.074(0.082)$ \\
\hline Education & $0.032(0.074)$ & $0.018(0.42)$ & $0.008(0.052)$ & $0.002(0.058)$ & $0.076(0.056)$ \\
\hline \multicolumn{6}{|l|}{ Predictors } \\
\hline ERCE & & $0.20 * *(0.044)$ & $0.10 *(0.066)$ & & $0.39 * *(0.028)$ \\
\hline CSR Authenticity & & & $0.38^{* *}(0.053)$ & & \\
\hline$R^{2}$ & 0.03 & 0.359 & 0.333 & 0.032 & 0.345 \\
\hline Adjusted $R^{2}$ & 0.018 & 0.361 & 0.331 & 0.024 & 0.325 \\
\hline Durbin-Watson & 1.576 & 2.075 & 2.051 & 1.651 & 2.554 \\
\hline
\end{tabular}

${ }^{*}=p<0.05 ;{ }^{* *}=p<0.01$. (Parentheses shows SE). 
The brief results of analysis and hypotheses tests is also shown in Figure 2.

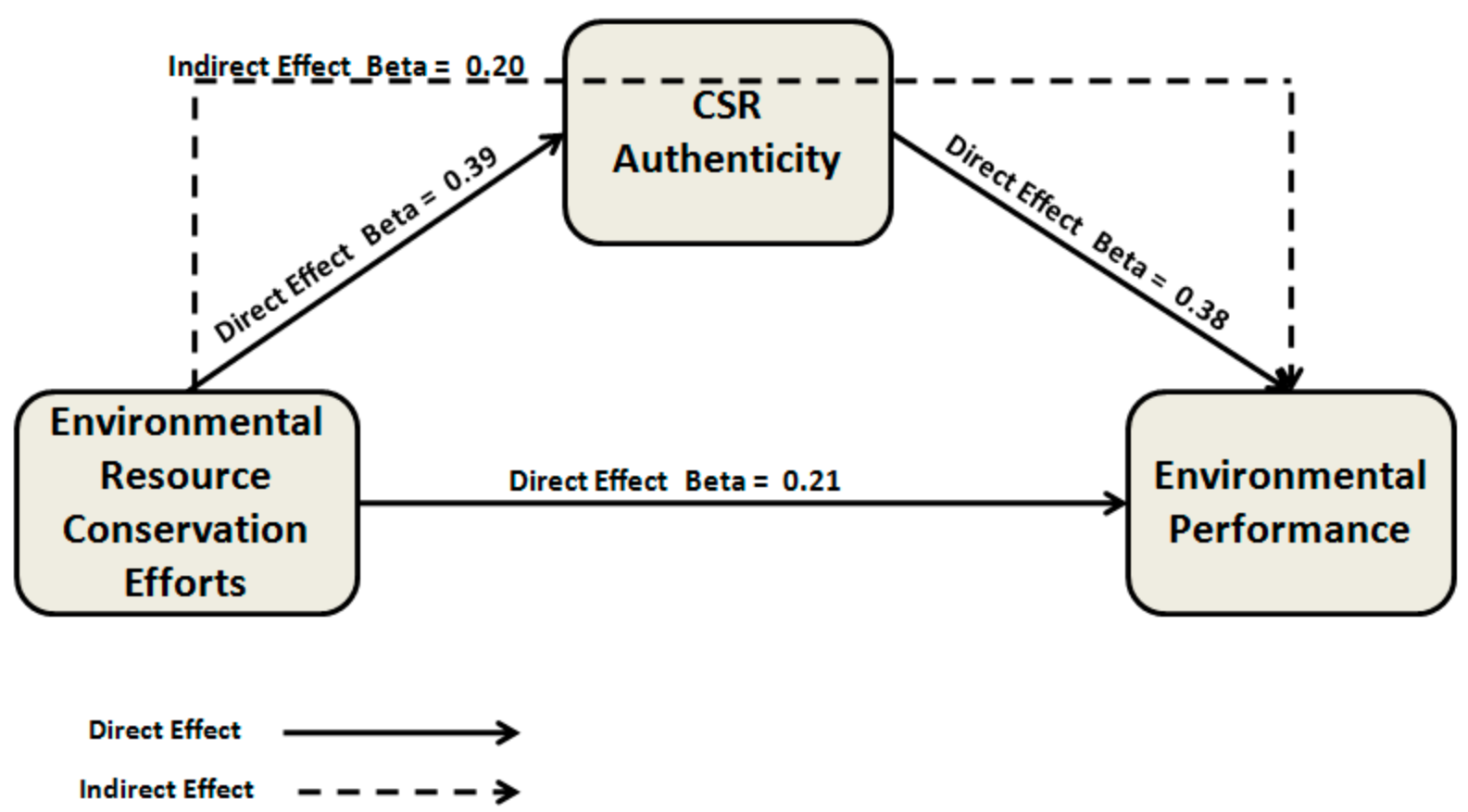

Figure 2. Results of Hypotheses.

\section{Discussion}

This research focused on the organizational level participation and the involvement in the concerns related to the environmental resource-conservation efforts and the CSR authenticity to acquire improved environmental performance. This research also focused on the mediation effect of the CSR authenticity in the association between the environmental resource-conservation efforts and the environmental performance of the organization. Four hypotheses have been proposed to empirically test the relationship between environmental resource-conservation efforts, CSR authenticity, and environmental performance. Concerning H1, the results showed the positive linkage between environmental resourceconservation efforts and environmental performance. These results support the prior researchers' work that environmental-resource conservation efforts are the practice of the skillful and rational management, use, and protection of natural resources of the environment $[34,38]$. It helps to boost and improve environmental performance through natural environmental resources for the betterment of mankind. Regarding Hypothesis 2, the study proves that environmental resource-conservation efforts of the firms positively influence CSR authenticity. These results are reliable with prior researchers' work that Environmental resource-conservation efforts positively effects affect the involvement of the firms in the CSR authenticity and help in the adoption of eco-friendly behavior [37]. Concerning H3, it was proposed that CSR authenticity can be positively associated with environmental performance. The result of this study support H3 and the work of previous research that CSR authenticity refers to the perception of the society and the stakeholders that are linked with firms that perform CSR activities for improvement and protection of the environmental performance [25]. However, the marginal level of association between the environmental resource-conservation efforts and the environmental performance shows that environmental resource-conservation effort is not a key factor for the improvement of environmental performance. So, this study gives an opportunity to find the internal mechanism, and this research fulfills this gap by testing mediating construct CSR authenticity. Hypothesis 4 of this study proves that environmental resource-conservation efforts predict environmental performance through CSR authenticity. Environmental resource-conservation efforts are pre-conditions of CSR authenticity which enhance the environmental performance of the 
organization. This study finding supports the work of prior studies that CSR authenticity acts as the bridge between the environmental resource-conservation efforts and the environmental performance because environmental resource-conservation efforts force organizations to participate in CSR-related actions and activities, which facilitates firms to promote environmental performance.

\section{Conclusions}

These results can provide some important policy and practical recommendations for the management of the organizations for increasing their environmental performance. This research has major practical implications by emphasizing the role of the environmental strategies and the authenticity of the CSR environmental-related activities to improve the environmental performance of the companies. The existing research lacks to achieve any clear and strong results about the impact of CSR authenticity on the environmental performance of the companies [48]. The study emphasized the role of a mediator (as CSR authenticity) for achieving environmental performance. Using a mediator between exogenous variables and the dependent variables represents a new approach in the analyses, and that is why this study significantly contributes to the existing literature. The important contribution is at the managerial level because it underlines the way CSR authenticity impacts corporate performance in the environmental area.The important role of the environmental initiatives for the authenticity of CSR was demonstrated by some recent studies [23,39], but this study elevates the existing knowledge by using the authenticity of CSR as a mediator in the relationship between conservational efforts of environmental resources and the environmental performance (dependent variable) as a major aim of this research.

This research extends the existing knowledge by providing an empiric model for the hospitality and tourism industry. Given the major role of the tourism industry, this model is an important outcome to guide the important role of EP in hotel businesses. This empiric model analyses the impact of the conservation efforts of the environmental resources and CSR authenticity on the environmental performance of the companies in the hospitality and tourism sector. The relation between the environmental management initiatives, CSR authenticity, and environmental performance of the companies was scarcely analyzed in the existing literature. The current research demonstrates that efforts of conservation of the environmental resources is a pre-request for enhancing CSR authenticity in the environmental area, and this, in its turn, contributes to the increase in the environmental performance of the companies in the hospitality and tourism sector $[49,50]$. The tourism and hospitality industries can achieve EP via environmental initiatives and the authenticity of CSR-related activities [51]. This model can be a very important managerial tool for hotel managers because it helps them to better understand the relation between the environmental initiatives, the authenticity of CSR, and environmental performance. The hotel managers should focus more on these inter-correlations and their strategic aims in the environmental area [52]. This way, they can achieve a long-term sustainable environmental performance for their corporations, and they can gain strong competitive advantages in this specific market [53]. Changing their hotels into green hotels will bring them a sustainable growth of tourists, and this can support both their environmental and economic performance in the long-run [54].

This research analyses the mediating role of CSR authenticity between the ERCE-EP link, but other organizational variables can be studied as mediators for enhancing this relationship. Another direction for further research would be to apply this analysis in other sectors, with different specific features, such as manufacturing industries or for SMEs that represent the major part of the economy.

\subsection{Theoretical Implications}

This study enriches the theory by adding the latest deliberations about the interplay between ERCE, CSR authenticity, and environmental performance. Environmental resource conservation efforts of an organization are related to the technical and operational efforts 
towards the reduction of energy, use of water, and waste. Through conservation efforts, companies can use pollution prevention techniques and minimize their emissions and waste, as well as reduce the negative effects of their production processes on the natural environment. ERCE initiates the mechanism of enabling an organization to be responsible for society and a clean environment. This study proved that both ERCE and CSR authenticity are major antecedents of EP.

Our study confirms that it is the environmental resource conservation efforts that result in taking different actions by organizations for enhancing EP. Since environmental resource conservation efforts play an important role for the sound environmental management regarding environmental issues, they are fully aware of the pros and cons of the business operations with respect to the environmental situation; apart from showing their concern for environmental problems through different job-related actions, it makes easy for the organizational management to meet the environmental goals. When organizations show their concern about the environment, it is expected that they will make efforts to protect it; therefore, an organization with environmental resource conservation efforts may collectively perform such acts, which lead to enhanced EP.

\subsection{Practical Implications}

This study suggests that environmental resource conservation efforts provide a foundation for EP. Organizations are now more concerned with hygienic issues and inclined towards green processes, green structures, and environmental consciousness. This study raised an upcoming issue by highlighting an important antecedent of EP, i.e., environmental resource conservation efforts. Moreover, the study suggests that managers must focus on a missing link of CSR between environmental resource conservation efforts and EP. Corrective actions by management and timely response stakeholders can ultimately strengthen the EP. Management in practice must focus on environmental resource conservation efforts and CSR for achieving overall EP. Study shows that organizational environmental resource conservation efforts provide technical and operational dynamism to execute CSR- and environmental-related activities for achieving the targets of EP.

Author Contributions: Conceptualization \& Administration, Z.Y.; original draft \& Formal analysis A.A.N.; investigation and methodology, M.R.; visualization, M.R.; software and data curation, M.H. All authors have read and agreed to the published version of the manuscript.

Funding: Funding for this study was supported by Researchers Supporting Project number (RSP2022/87), King Saud University, Riyadh, Saudi Arabia.

Institutional Review Board Statement: IRB Letter Approval Ref: GCMS-ADM/69/2022. Informed Consent Form Attached.

Informed Consent Statement: Informed consent was obtained from all subjects involved in the study.

Data Availability Statement: Not applicable.

Acknowledgments: Researchers Supporting Project number (RSP-2022/87), King Saud University, Riyadh, Saudi Arabia.

Conflicts of Interest: The authors declare no conflict of interest.

\section{References}

1. Anser, M.K.; Yousaf, Z.; Khan, M.A.; Nassani, A.A.; Abro, M.M.Q.; Vo, X.H.; Zaman, K. Social and administrative issues related to the COVID-19 pandemic in Pakistan: Better late than never. Environ. Sci. Pollut. Res. 2020, 27, 34567-34573. [CrossRef] [PubMed]

2. Baker, W.E.; Sinkula, J.M. Environmental marketing strategy and firm performance: Effects on new product performance and marketshare. J. Acad. Mark. Sci. 2005, 33, 461-474. [CrossRef]

3. Birindelli, G.; Iannuzzi, A.P.; Savioli, M. The impact of women leaders on environmental performance: Evidence on gender diversity in banks. Corp. Soc. Responsib. Environ. Manag. 2019, 26, 1485-1499. [CrossRef]

4. Deng, X.; Lu, J. The environmental performance, corporate social responsibility, and food safety of food companies from the perspective of Green finance. Rev. Cercet. Interv. Soc. 2017, 58, 178-200. 
5. Gössling, S. Sustainable Tourism Development in Developing Countries: Some Aspects of Energy Use. J. Sustain. Tour. 2000, 8, 410-425. [CrossRef]

6. Nepal, S.K. Tourism-induced rural energy consumption in the Annapurna region of Nepal. Tour. Manag. 2008, 29, 89-100. [CrossRef]

7. Hatipoglu, B.; Ertuna, B.; Salman, D. Corporate social responsibility in tourism as a tool for sustainable development: An evaluation from a community perspective. Int. J. Contemp. Hosp. Manag. 2019, 31, 2358-2375. [CrossRef]

8. Khatter, A.; McGrath, M.; Pyke, J.; White, L.; Lockstone-Binney, L. Analysis of hotels' environmentally sustainable policies and practices: Sustainability and corporate social responsibility in hospitality and tourism. Int. J. Contemp. Hosp. Manag. 2019, 31, 2394-2410. [CrossRef]

9. Arimura, T.H.; Hibiki, A.; Katayama, H. Is a voluntary approach an effective environmental policy? A case for environmental management system. J. Environ. Econ. Manag. 2007, 55, 281-295. [CrossRef]

10. Henri, J.-F.; Journeault, M. Environmental performance indicators: An empirical study of Canadian manufacturing firms. J. Environ. Manag. 2008, 87, 165-176. [CrossRef]

11. Hamschmidt, J. Economic and Ecological Impacts of Environmental ManagementSystems in Companies: Experience from Switzerland. Presented at EuroEnvironment 2000-Visions; Strategies and Actions Towards Sustainable Industries, Aalborg, Denmark, 18-20 October 2000.

12. Gallez, C.; Tyteca, D. Explaining the Environmental Performance of Firms with Indicators. In Ecosystems and Sustainable Development_Advances in Ecological Sciences; Usó, J.L., Brebbia, C.A., Power, H., Eds.; WIT Press: Southampton, UK, 1998; Volume 1, pp. 317-330.

13. Hertin, J.; Berkhout, F.; Wagner, M.; Tyteca, D. Are EMS environmentally effective? The link between environmental management systems and environmental performance in European companies. J. Environ. Plan. Manag. 2009, 51, 259-283. [CrossRef]

14. Hsiao, T.-Y.; Chuang, C.-M.; Kuo, N.-W.; Yu, S.M.-F. Establishing attributes of an environmental management system for green hotel evaluation. Int. J. Hosp. Manag. 2014, 36, 197-208. [CrossRef]

15. Melnyk, S.A.; Sroufe, R.P.; Calantone, R. Assessing the impact of environmental management systems on corporate and environmental performance. J. Oper. Manag. 2003, 21, 329-351. [CrossRef]

16. Endo, K. Does the stock market value corporate environmental performance? Some perils of static regression models. Corp. Soc. Responsib. Environ. Manag. 2019, 26, 1530-1538. [CrossRef]

17. Johnstone, N.; Glachant, M.; Serravalle, C.; Riedinger, N.; Schapecchi, P. Many a Slip 'Twixt the Cup and the Lip: Direct and Indirect Policy Incentives to Improve Environmental Performance. In Environmental Policy and Corporate Behaviour; Johnstone, N., Ed.; Edward Elgar Publishing: Northampton, MA, USA, 2007.

18. Labonne, J. A Comparative Analysis of the Environmental Management, Performance and Innovation of SMEs and Larger Firms, European Commission Report, Directorate-General Environment. 2006. Available online: https://ec.europa.eu/environment/ archives/sme/pdf/final_report_sme_en.pdf (accessed on 10 November 2020).

19. Alhouti, S.; Johnson, C.M.; Holloway, B.B. Corporate social responsibility authenticity: Investigating its antecedents and outcomes. J. Bus. Res. 2016, 69, 1242-1249. [CrossRef]

20. Husted, B.W.; de Sousa-Filho, J.M. The impact of sustainabilitygovernance, country stakeholder orientation, and country risk on environmental, social, and governanceperformance. J. Clean. Prod. 2017, 155, 93-102. [CrossRef]

21. Songmi, K.; Heejung, L. The Effect of CSR Fit and CSR Authenticity on the Brand Attitude. Sustainability 2019, $12,275$.

22. Wiengarten, F.; Pagell, M. The importance of quality management for the success of environmental management initiatives. Int. J. Prod. Econ. 2012, 140, 407-415. [CrossRef]

23. Choi, H.M.; Kim, W.G.; Kim, Y.J.; Agmapisarn, C. Hotel environmental management initiative (HEMI) scale development. Int. J. Hosp. Manag. 2019, 77, 562-572. [CrossRef]

24. Molina-Azorín, J.F.; Tarí, J.J.; Pereira-Moliner, J.; Lopez-Gamero, M.D.; Pertusa-Ortega, E.M. The effects of quality and environmental management on competitive advantage: A mixed methods study in thehotelindustry. Tour. Manag. 2015, 50, 41-54. [CrossRef]

25. Lin, K.; Peng, M.Y.; Anser, M.K.; Yousaf, Z.; Sharif, A. Bright harmony of environmental management initiatives for achieving corporate social responsibility authenticity and legitimacy: Glimpse of hotel and tourism industry. Corp. Soc. Responsib. Environ. Manag. 2020, 28, 640-647. [CrossRef]

26. Berkhout, F. Rationales for adaptation in EU climate change policies. Clim. Policy 2005, 5, 377-391. [CrossRef]

27. De Roeck, K.; Delobbe, N. Do environmental CSR initiatives serve organizations' legitimacy in the oil industry? Exploring employees' reactions through organizational identification theory. J. Bus. Ethics 2012, 110, 397-412. [CrossRef]

28. Anser, M.K.; Yousaf, Z.; Usman, M.; Yousaf, S. Towards strategic business performance of the hospitality sector: Nexus of ICT, E-marketing and organizational readiness. Sustainability 2020, 12, 1346. [CrossRef]

29. Majid, A.; Yasir, M.; Yousaf, Z.; Qudratullah, H. Role of networkcapability, structural flexibility and management commitment in definingstrategic performance inhospitality industry. Int. J. Contemp. Hosp. Manag. 2019, 31, 3077-3096. [CrossRef]

30. Khan, A.; Bibi, S.; Ardito, L.; Lyu, J.; Hayat, H.; Arif, A.M. Revisiting the Dynamics of Tourism, Economic Growth, and Environmental Pollutants in the Emerging Economies-Sustainable Tourism Policy Implications. Sustainability 2020, $12,2533$. [CrossRef] 
31. Beaudoin, C.A.; Cianci, A.M.; Hannah, S.T.; Tsakumis, G.T. Bolstering Managers' Resistance to Temptation via the Firm's Commitment to Corporate Social Responsibility. J. Bus. Ethics 2019, 157, 303-318. [CrossRef]

32. Anser, M.K.; Yousaf, Z.; Majid, A.; Yasir, M. Does corporate social responsibility commitment and participation predict environmental and social performance? Corp. Soc. Responsib. Environ. Manag. 2020, 27, 2578-2587. [CrossRef]

33. Yousaf, Z.; Radulescu, M.; Sinisi, C.; Serbanescu, L.; Paunescu, L. Harmonization of Green Motives and Green Business Strategies towards Sustainable Development of Hospitality and Tourism Industry: Green Environmental Policies. Sustainability 2021, 13, 6592. [CrossRef]

34. Martín, C.J.G.; Herrero, B. Do board characteristics affect environmental performance? A study of EU firms. Corp. Soc. Responsib. Environ. Manag. 2020, 27, 74-94. [CrossRef]

35. Memon, A.; An, Z.Y.; Memon, M.Q. Does financial availability sustain financial, innovative, and environmental performance? Relation via opportunity recognition. Corp. Soc. Responsib. Environ. Manag. 2020, 27, 562-575. [CrossRef]

36. Gilal, F.G.; Ashraf, Z.; Gilal, R.G.; Chaana, N.A. Promoting environmental performance through green human resource management practices in higher education institutions: A moderated mediation model. Corp. Soc. Responsib. Environ. Manag. 2019, 26, 1579-1590. [CrossRef]

37. Wang, F.; Peng, X.; Wei, R.; Qin, Y.; Zhu, X. Environmental behavior research in resources conservation and management: A case study of Resources, Conservation and Recycling. Resour. Conserv. Recycl. 2019, 141, 431-440. [CrossRef]

38. Olalekan, R.M.; Omidiji, A.O.; Williams, E.A.; Christianah, M.B.; Modupe, O. The roles of all tiers of government and development partners in environmental conservation of natural resource: A case study in Nigeria. MOJ Ecol. Environ. Sci. 2019, 4, 114-121. [CrossRef]

39. Lee, S.; Yoon, J. Does the authenticity of corporate social responsibility affect employee commitment? Soc. Behav. Personal. Int. J. 2018, 46, 617-632. [CrossRef]

40. Hodges, C. Law and Corporate Behaviour: Integrating Theories of Regulation, Enforcement, Compliance and Ethics; Bloomsbury Publishing: Oxford, UK, 2015.

41. Williamson, D.; Lynch-Wood, G.; Ramsay, J. Drivers of Environmental Behaviour in Manufacturing SMEs and the Implications for CSR. J. Bus. Ethics 2006, 67, 317-330. [CrossRef]

42. Gunawan, S.; Budiarsi, S.Y.; Hartini, S. Authenticity as a corporate social responsibility platform for building customer loyalty. Cogent Bus. Manag. 2020, 7, 1775023. [CrossRef]

43. Prasad, M.; Mishra, T.; Bapat, V. Corporate social responsibility and environmental sustainability: Evidence from India using energy intensity as an indicator of environmental sustainability. IIMB Manag. Rev. 2019, 31, 374-384. [CrossRef]

44. Durach, C.F.; Wiengarten, F. Environmental management: The impact of national and organizational long-term orientation on plants' environmental practices and performance efficacy. J. Clean. Prod. 2017, 167, 749-758. [CrossRef]

45. Cooper, B.; Eva, N.; Fazlelahi, F.Z.; Newman, A.; Lee, A.; Obschonka, M. Common method variance in vocational behaviour research: Reviewing the state of the literature. J. Vocat. Behav. 2020, 121, 103472. [CrossRef]

46. Tuan, L.T. Catalyzing Employee OCBE in Tour Companies: Charismatic Leadership, Organizational Justice, and Pro Environmental Behaviors. J. Hosp. Tour. Res. 2019, 43, 682-711. [CrossRef]

47. Srinivasan, R.; Lohith, C.P. Pilot Study-Assessment of Validity and Reliability. In Strategic Marketing and Innovation for Indian MSMEs; India Studies in Business and Economics; Springer: Singapore, 2017. [CrossRef]

48. Solovida, G.; Latan, H. Linking environmental strategy to environmental performance: Mediation role of environmental management accounting. Sustain. Account. Manag. Policy J. 2017, 8, 595-619. [CrossRef]

49. Wagner, M. How to reconcile environmental and economic performance to improve corporate sustainability: Corporate environmental strategies in the European paper industry. J. Environ. Manag. 2005, 76, 105-118. [CrossRef] [PubMed]

50. Latan, H.; Jabbour, C.J.; Jabbour, A.B.; Wamba, S.F.; Shahbaz, M. Effects of environmental strategy, environmental uncertainty and top management's commitment on corporate environmental performance: The role of environmental management accounting. $J$. Clean. Prod. 2018, 180, 297-306. [CrossRef]

51. Yasir, M.; Majid, A.; Yasir, M.; Qudratullah, H. Promoting environmental performance in manufacturing industry of developing countries through environmental orientation and green business strategies. J. Clean. Prod. 2020, 275, 123003. [CrossRef]

52. Chung, K.C. Green marketing orientation: Achieving sustainable development in green hotel management. J. Hosp. Mark. Manag. 2020, 29, 722-738. [CrossRef]

53. Kazmi, M.; Shah, S.A.H. Six Sigma, a road to infallible service quality in hotel industry of Pakistan. Artech J. Tour. Res. Hosp. 2020 1, 6-12.

54. Balaji, M.S.; Jiang, Y.; Jha, S. Green hotel adoption: A personal choice or social pressure? Int. J. Contemp. Hosp. Manag. 2019, 31, 3287-3305. [CrossRef] 